\title{
Evidence of the Determinants of Audit Quality: A Non-governmental Organisations Perspective in Uganda
}

\author{
Festo Nyende Tusubira* Jude Thaddeo Mugarura David Namanya \\ College of Business and Management Sciences, Makerere University, P.O. Box 7062, Kampala, Uganda
}

\begin{abstract}
While audit quality has been widely investigated on the global scale, little research has been conducted on the determinants of Audit quality for non-governmental organizations (NGOs) and in the context of Uganda. This article is motivated by the unending observations of audit quality determinants being unclear and indecisive. Using a cross sectional research design and a quantitative approach with the aid of a self-administered questionnaire, this article investigates what the finance/procurement managers for NGOs in Uganda perceive to be the key quality determinants for the work done by auditors. Whereas results generally reveal that auditor fees, auditor firm size, auditor competence, auditor independence, and number of audit assignments significantly relate with audit quality, auditor tenure and auditor age were found to have insignificant effects on audit quality. This article therefore provides more insightful evidence about the ongoing discussions on the determinants of audit quality for NGOs in Sub-Saharan African, particularly from the Ugandan perspective.
\end{abstract}

Keywords: Audit quality, auditor competence, firm size, auditor tenure, auditor fees, NGOs, Uganda.

DOI: $10.7176 / \mathrm{DCS} / 11-6-04$

Publication date:June $30^{\text {th }} 2021$

\section{Introduction}

Audit is a governance function to which auditors express opinions regarding the truthfulness and fairness of the financial and other operational statements ( for example, on procurement systems, structures and processes) associated with activities undertaken by reporting organisations (Tumwebaze, Mukyala, Ssekiziyivu, Tirisa, \& Tumwebonire, 2018). As such audits would provide the assurance and confidence to the users about the actual performance as well as the correct reporting of performing organisations (Bananuka, Nkundabanyanga, Nalukenge, \& Kaawaase, 2018). At an individual level, auditors thus have a duty to nurture their expertise, have the appropriate qualifications, and develop the right skills to deliver financial and procurement statement opinions among others that are relevant unbiased, and of accurate position; and at an organizational level, many other factors are at play including internal control systems of the performing firm and the size of the audit firm, though audit firm size has had mixed responses (Al-Khaddash, Al Nawas \& Ramadan, 2013).

Different authorities provide guidance to the audit profession (See, The US Advisory Committee on the Auditing Profession, 2008; The Australia Treasury Audit Quality - a Strategic Review, 2010; The UK Financial Reporting Council-Audit Quality Framework, 2008), but with limited focus on the quality of audits for NGOs, yet NGOs have tremendously grown in number and donors heavily fund them with the belief that they have the potential to fill the public service delivery gaps of government (Damba, 2018; MIA Press Release, 7th August 2019). Such makes auditing and determining of the true performance of NGOs very challenging (Lehman, 2007; Humanitarian Financing Task Team, 2016; Joint Inspection Unit, 2017). While more recently audit guidelines have become paramount for the operations of NGOs, globally the credibility of their audit processes, audit outcomes, auditors' role and the overall corporate governance aspects remain questionable (Horvat \& Bobek, 2019). This has led to the formulation of policy measures such as a ban on audit firms taking on non-audit services, rapid adoption of Sarbanes Oxley Act (SOX) and internal auditor independence by not undertaking self-reviews (Al-Khaddash, et al., 2013).

Notwithstanding the aforementioned audit reforms, empirical evidence still shows that the determinants of audit quality are unclear and indecisive (Kaawaase, Assad, Kitindi, \& Nkundabanyanga, 2016). This study offers empirical evidence on the perceptions of what determines the quality of audit with regard to audit firm characteristics and the usefulness of audit teams to ensure trustworthiness and confidence of the public in the audit report outcomes and the integrity of the financial reporting system of NGOs (Shockley, 1981; Pany \& Reckers 1988).

Exploring audit quality in Ugandan NGO sector is noteworthy based on the prominence of getting a high quality audit process in the Ugandan non-governmental organisations. One of the momentous sectors in Uganda is the NGO sector which is important in the Ugandan economy with the role of bridging the gaps that government funding and operations may not sufficiently reach or cover but also creating efficiency in public service provision. However, Kaawaase et al. (2016) reveal challenges in measuring audit quality in both developed and emerging economies. Revelations in the New Vision as reported by Mubiru (2020) indicate that some accountants do not perform audits to the level of quality expected of them, calling for disciplinary action by the Institute of Certified Public Accountants of Uganda, the Institute of Procurement Professionals of Uganda as well as the Public 
Procurement and Disposal of Public Assets Authority. Inappropriate audit quality might be against high risks of corruption, the potential for fraud and unethical business practices, extreme poverty and conflict among others in environments where these NGOs operate, Uganda inclusive (Manley, 2018). Kasigwa, Munene, Ntayi, \& Nkote (2013) find that some auditors engage in practices like accepting client explanations to audit issues to substitute other audit evidence that can be got as well. Such practices can potentially reduce the audit quality. Also, low financial and procurement accountability is cited among Uganda's non-profit organisations, reporting 31 percent of them not having complete financial and procurement information or having information with significant errors (Dang, Burger, \& Owens, 2019). This is against objectives of audits that are intended to support NGOs in order to take corrective actions over their financial and procurement information. This can be interpreted as a sign of lapses in audit quality. Exploring audit quality practices in non-governmental organisations' sector might support improved accountability within this sector. The aim of this study therefore is to examine the determinants of auditing quality in the Ugandan NGOs from the viewpoints of their finance/procurement managers, and to make a contribution to the existing audit quality literature.

\subsection{Theoretical framework}

The services of auditors are demanded as monitoring tools due to potential conflicts of interest between business owners and those among different shareholders which can increase agency costs (see Watts, 1977; Benston, 1980; Watts \& Zimmerman, 1981). To ably execute their monitoring role, auditors should be independent with reasonable tenure (Kaawaase \& Nkundabanyanga, 2017), competent (Ferdinand, Syaifuddin, Dali, \& Masud, 2019), and their firm size (Ndubuisi \& Ezechukwu, 2017), fees (Choi, Kim and Zang, 2010), number of audit assignments and auditor age (Persson, 2011) should be of reasonable magnitude. Audit quality as an output of the audit process is a sign that auditors are effectively undertaking their role of monitoring management activities (Chersan, 2019) as guided by the agency theory.

\section{Literature review}

In absence of an inclusive audit quality definition covering the different categories of audits and auditors (AlKhaddash, et al., 2013), we adopt the definition from DeAngelo (1981) that refers to audit quality as a probability that the auditor will both discover and report a breach in the client's accounting and procurement system based on the applicable audit standards and procedures. This description is suitable for both external and internal audits whether programmatic or compliance in nature.

Audit quality comes into play when the principal engages an agent to perform a service on his/her behalf. The principal-agent relationship implies that the principal trusts the agent to act in his/her best interests, which may not always be the case as the agent might instead work against the principal's interests. This suggests that an auditor must be deployed to oversee the performance of the agent (Retzl, 2017).

Several studies reveal that audit quality might be guaranteed by employing auditors who have the right experience, are honest and with the knowledge and skills in accounting, procurement and auditing standards (DeAngelo, 1981; Hameed, 1995). On the other hand, Alqam and Alrajabi (1997), and Abbott and Parker (2000) discovered that auditor rotation could be very appropriate for audit quality assurance but noted that such might only be influenced by management replacement, audit office, enthusiastic and independent audit committees, and international auditing standards and ethical requirements. Furthermore, Abbott, Parker, Peters and Raghunandan (2003) and Abbott, Parker and Peters (2004) acknowledge that an independent and active audit committee are more likely to demand greater audit quality level arising from monetary and reputational loss trepidations. Kaawaase and Nkundabanyanga (2017) contend that auditor independence is critical in ensuring that the interests of stakeholders are safeguarded, and such is consistent with Brown et al. (2006) recognition of auditor independence enhancing financial and/or procurement disclosure quality. Finally, Omonuk and Oni (2015) established that developing country firms that employ computer assisted audit techniques (CAATs) yield positive and significant influence on audit quality as opposed to those that apply traditional methodologies. Aroused by the fact that firm and individual characteristics are generally associated with audits (DeAngelo, 1981; Hameed, 1995; Parker et al. 2003; Brown et al. 2006), we hypothesize that audit quality for NGOs in Uganda may be influenced by firm size, auditor fees, auditor independence, auditor tenure, auditor competence, number of audit assignments, and the age of the auditor.

\subsection{Firm size and audit quality}

Big Audit firms are presumed to conduct more accurate tests therefore more likely to be associated with precise information than their small audit firms as a way of protecting the brand name and reputation of the organisation for business continuity. Auditor independence, competence and associated with larger forecast errors as characteristics of firm size which are indeed positively related with audit quality (Suseno \& Nofianti, 2018; Beatty, 1989).

Big audit firms are well structured in terms of talented employees and superior technology which may support 
their advanced audit performance compared to small audit firms (Ndubuisi \& Ezechukwu, 2017; Francis \& Wilson, 1988; DeAngelo, 1981), and can exert more pressure on management because of their client portfolios (Mahdi \& Ali, 2009; Lys \& Watts, 1994). The expectation is that financial and procurement statements that have been audited by large firms will have minimal errors and misstatements arising from self-interests (Rezaei \& Shabani, 2014). Dopuch and Simunic (1982) note that audit quality is a function of the number of and the extent to which audit procedures are performed, and tasks that big audit firms can easily do as they have access to more resources than small audit firms. This implies that where firm size and audit quality are positively associated, large differences are likely to exist between reported and forecasted incomes for entities audited by large auditors than with small auditors after controlling for client risky characteristics (Rezaei \& Shabani, 2014). In a conducted experiment of six large and small audit firms, Krishnan and Schauer (2000) found out that compliance increases as one moves from the small to large audit firm size category, while because large audit firms have the capacity to employ a reasonable number of professional auditors than small audit firms can do.

H1: Audit firm size have an effect on audit quality.

\subsection{Auditor fees and audit quality}

According to Hoitash, Markelevich and Barragato (2007) auditor fees refers to costs that client organizations incur to pay for the audit and other accompanying services provided by audit firms. Such fees are meant to enable field and office staff undertake field audit activities, as well as assure the audit firm of the realization of the expect profit of the audits pursued. The common ways of arriving at audit fees to be charged are low-balling (where the auditor sets low audit fees for a new client) and the estimated cost plus margin (the costs that the auditor expects to spend on the assignment and adds a percentage for the profit) (Kinney \& Libby, 2002). Francis and Simon (1987) suggest that audit fees differentiate the quality of audits to be provided in a competitive world. Deis and Giroux (1996) asserts that client organizations are likely to pay higher audit fees (premium inclusive) as long as they believe that the auditors will deliver high quality audit services. While there is enough evidence showing audit premiums to be an important component of the audits (Al-Khaddash, et al., 2013; Craswell, Francis \& Taymor,1995), such may not always be the case (Chaney, Jeter \& Shivakumar, 2002). Under normal circumstances a moderate audit premium fee should be offered since excessively high audit fees tend to compromise the auditors' reporting (Choi, Kim and Zang, 2010).

Notwithstanding the mixed evidence on the relationship between audit fees and audit quality, with the Ugandan context, we hypothesize as follows;

H2: Auditor fees affect audit quality among the NGO sector in Uganda.

\subsection{Auditor independence and audit quality}

According to Gay and Simnett (2003: 745) Auditor independence is the 'ability to withstand pressure from management influence when conducting an audit or providing audit-related services, so that the professional integrity of the auditor is not compromised'. Auditor independence is thus a fundamental principle that underlies and influences the work of external and internal auditors, preparers and users of financial and procurement performance statements (Moore et al., 2006). Note that auditor Independence must be enhanced by instituting an independent audit committee that would ensure the decisions of both internal and external auditors are free from management influence (Kaawaase \& Nkundabanyanga, 2017; Caswell \& Allen, 2001).

A study conducted in Uganda, Warabyeki (2008) established auditor engagement controls, internal governance controls, and the oversight of auditors to improve auditor independence, and so would be audit quality. Observance of auditor independence and audit quality seem to be anchored predominantly in having sound audit performance measures as well as the motivation of the auditors and other stakeholders to comply with the ongoing professional ethical standards (Ponemon \& Gadhart,1990).

According to Al-Khaddash et al. (2013) experienced auditors are likely to be more independent and produce better audit quality reports than unexperienced auditors since they can tactfully resist client management pressures and negotiate with ease over performance reporting concerns. In summary therefore, auditor independence is paramount in the delivery of quality audit work (Hardiningsih et al., 2019).

H3: Auditor independence has a positive effect on audit quality.

\subsection{Auditor competence and audit quality}

Auditors are expected to possess the required professional competences acquired through formal education, professional certification, participation in symposia, seminars, trainings and experience (Hardiningsih et al. 2019; Zu'amah, 2009) to perform their work well. Such assertion implores smart auditors to strive to uphold competence through continuous professional knowledge update in order to compete fairly in the audit global market. Auditor competence is therefore expected to support in understanding the business run processes to enhance the audit procedures that would help in producing better quality audit reports (Ferdinand, Syaifuddin, Dali, \& Masud, 2019; Christiawan, 2002). 


\section{H4: Auditor competence has a significant effect on audit quality}

\subsection{Auditor tenure and audit quality}

Tenure is when the auditor holds a long-standing relationship with the client. This condition emboldens a profounder appreciation of the client's financial and procurement condition (Hardiningsih et al. 2019). There are two contrasting views relating to the effects of auditor tenure on audit quality. The first being, the longer the auditor-client relationship becomes the more likely will he auditor develop a closer relationship with a client, something that may prompt an auditor o serve management interests for such organization (Ndubuisi \& Ezechukwu, 2017; González-Díaz, García-Fernández, \& López-Díaz, 2015). Such view calls for mandatory audit partner rotation. As well, a long tenure tends to encourage the auditors to lose the professional skepticism by applying weak audit procedures that can essentially favour the clients in case client's behavior remains unchanged overtime (Kaawaase \& Nkundabanyanga, 2017). Such would reduce audit quality due to compromised independence, professional care and innovativeness of the auditors (Hardiningsih et al. 2019; Vanstraelen, 2000). The other view is that, "auditors understanding of the clients' business increases as the auditor tenure grows and so is audit quality because auditors would have developed audit expertise to discover misstatements with the technical capabilities and knowledge acquired (Vanstraelen, 2000) during the course of their work. This is consistent with prior studies that have highlighted that long auditor tenure may not impair audit (Knechel, \& Vanstraelen, 2007; Lim, Tan, \& Cheng, 2010).

H6: Auditor tenure affects audit quality

2.6 Number of audit assignments and audit quality

The Financial Supervisory Authority of Norway Report (2010) suggest that the number of audits one handles reduces the amount time an auditor would spend to complete subsequent audit assignments. This, according to Persson (2011) can pose a risk of reduced quality control mechanisms which automatically undermines audit quality. According to Watts and Zimmerman (1986) auditors ensure that corporations comply with policies, laws and regulations but if at any one time they hold many client commitments, this condition might overstretch their ability to perform their duties appropriately. In such a case the concentration of the auditors might be on getting excessive compensation than realizing the best audit outcome (Core, Holthausen \& Larcker, 1999).

The foregoing argument though, does not consider the other side of holding many assignments. Bauwhede and Willekens (2004) support the concept of holding a number of audit assignments for improved auditors' performance. According to Vander Bauwhede and Willekens (2004) many audits are more beneficial because such further the competence and experience of auditors in their professional work auditor. An implication that with fewer assignments the quality of audit work would be lower.

H7: The number of audit assignments significantly affects audit quality.

\subsection{Auditor's age and audit quality}

Often society believes the older one becomes as an employee the less the outputs that a person produces (Rhodes, 1983; Persson, 2011). However, most of the studies that Rhodes (1983) examines provide mixed results about the influence of age on audit quality. Findings therefore present inconclusive evidence.

Similarly, Conroy, Emerson and Pons (2010) in their study on ethics in relation to age of auditors at different ranks provided divergent opinions. For instance, auditors at managerial level exhibited more acceptance for questionable ethical issues than lower level and young auditors (Conroy et al. 2010). Such provides the evidence that older auditors are capable of producing quality audits than their younger counterparts.

H8: Auditors' age significantly affects audit quality.

\section{Methodology}

A cross-sectional quantitative research survey design (Kothari, 2002) with self-administered questionnaires were employed to collect data from respondents. Questionnaires were distributed to finance/procurement managers in Uganda working for NGOs. While initially the interest was to collect data from individuals with finance and procurement expertize separately, only finance personnel were used since it was later discovered that unlike public sector entities most NGOs in Uganda, the finance personnel perform most of the procurement tasks. The article uses purposive sampling to identify 382 finance/procurement personnel that work with NGOs. We received back a total of 246 questionnaires (representing 64.4\%) that were valuable for the study analysis. Table 1 below shows a summary of the respondents' characteristics in terms of formal education level, whether they have accountancy/procurement professional qualification, and their position within their organisation. These characteristics mutually suggest that respondents had the knowledge and experience required to provide valuable survey responses. 
Table 1: The demographic background

\begin{tabular}{|c|c|c|c|c|c|c|c|}
\hline Variable $(N=246)$ & Freq. & $\%$ & Mean & SD & Var & Min. & Max. \\
\hline Position & & & 0.46 & 0.29 & .21 & 0 & 1 \\
\hline Finance/procurement manager & 246 & 100 & & & & & \\
\hline Gender & & & 0.42 & .49 & .25 & 0 & 1 \\
\hline Male & 162 & 65.85 & & & & & \\
\hline Female & 84 & 34.15 & & & & & \\
\hline Age of respondent & & & 2.96 & .67 & .45 & 1 & 6 \\
\hline Below 19 & 0 & 0 & & & & & \\
\hline $19-30$ & 52 & 21.14 & & & & & \\
\hline $31-40$ & 134 & 54.47 & & & & & \\
\hline $41-50$ & 44 & 17.89 & & & & & \\
\hline $51-60$ & 16 & 6.50 & & & & & \\
\hline Over 60 & 0 & 0 & & & & & \\
\hline Qualification of the respondent & & & 2.58 & .98 & .97 & 1 & 4 \\
\hline Diploma & 13 & 5.29 & & & & & \\
\hline Bachelors & 196 & 79.68 & & & & & \\
\hline Masters & 32 & 13.00 & & & & & \\
\hline $\mathrm{PhD}$ & 5 & 2.03 & & & & & \\
\hline Professional certification & & & 0.84 & .86 & .57 & 0 & 1 \\
\hline Yes & 207 & 84.15 & & & & & \\
\hline No & 39 & 15.85 & & & & & \\
\hline No. of years of audit work & & & 2.21 & .92 & .55 & 1 & 3 \\
\hline 3 years or less & 48 & 19.51 & & & & & \\
\hline $4-10$ years & 157 & 63.82 & & & & & \\
\hline Over 10 years & 41 & 16.67 & & & & & \\
\hline
\end{tabular}

Source: Primary data

3.1 Data collection instrument and measures

The instrument is divided into eight sections: section 1 provides the respondents' demographic and background information. Section 2 to section 8 were dedicated to issues that extant literature identifies from previous scholarships (DeAngelo, 1981; Beatty, 1989; Deis \& Giroux, 1992; Kaawaase \& Nkundabanyanga, 2017; Hardiningsih et al. 2019; Abbott et al., 2016; Knechel, \& Vanstraelen, 2007) that determine audit quality. We identify five issues related to audit quality, five issues on auditor firm size, three on auditor fees, nine on auditor independence, six on auditor competence, and five on auditor tenure and three on the number of audit assignments handled by an auditor. These issues were then anchored on a five-point Likert scale asking respondents as to whether in their opinion the different categories of issues would affect audit quality, whereby $1=$ strongly disagree to $5=$ strongly agree. These scales have been reviewed for correctness and applicability in the Ugandan setting with the help of 10 experts. A Content Validity Index of 0.80 and above for all issues in the questionnaire were obtained, indicating acceptable validity of the research for the pre-test.

\subsection{Data analysis tools}

The researchers used SPSS version 23 to analyse the data. First, simple frequency runs were to identify and fill missing data, and subsequently, validity and reliability tests, and correlation and multiple regressions were conducted. Principal component analysis and Cronbach's alpha $(\alpha)$ coefficients were used to examine the validity and reliability of the scales as measures of audit quality, auditor fees, auditor independence, auditor fees, firm size, auditor competence, number of audit assignments handled by an auditor and auditor tenure. Principal components analysis using Varimax rotation method was used to establish convergent validity by extracting 7 suppressed factor loading coefficients to avoid lower loadings lower than 0.5 . We also examined the appropriateness of the data for factor analysis based on the sample size adequacy, the Kaisa-Meyer-Olkin (KMO) and the Bartlett's test of sphericity. The KMO value from the test for all the factors was 0.889 and, the Bartlett's test of sphericity for all the scales was statistically significant $(p<0.001)$. These results generally support the factorability of the correlation matrices since they are significantly different from the identity matrices in which the variables might not correlate with one another, hence absence of multicollinearity.

Tests for reliability of all our scales reveal Cronbach's $\alpha$ coefficients were above 0.7 (audit quality $\alpha=.813$; firm size $\alpha=.811$ auditor fees $\alpha=.801$; auditor independence $\alpha=.899$; auditor competence $\alpha=.798$; auditor 
tenure $\alpha=.776$; number of audit assignments $\alpha=.788$ ), hence internal consistency of the instrument (Hair, Black, Babin, \& Anderson, 2010). Table 2 below shows the percentage variance of 93.6 in the entire model of the determining variable factors of audit quality among NGOs in Uganda.

Table 2: Rotated PCA for the variable factors of the study.

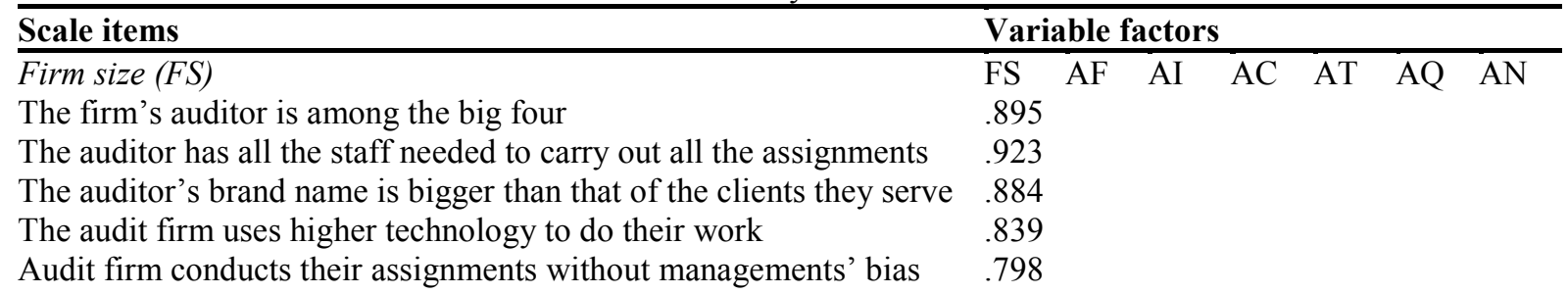

Auditor fees $(A F)$

Auditor charges match the work that audit firms do

Our firm regularly pay higher fees if they find it appropriate

Higher auditor fees support auditors to do their work objectively

Auditor independence (AI)

There is regulation of clients that are audited

Our firm usually has proper governance structures constituted

There is rotation of audit firms and audit partners

$\begin{array}{ll}\text { There is fear of disciplinary action by professional bodies } & .799\end{array}$

$\begin{array}{ll}\text { There is a risk of auditor reputation from public scandals } & .794\end{array}$

$\begin{array}{ll}\text { There is a requirement of annual auditor reappointments } & .773\end{array}$

Auditors are required to obtain expert clearance from outgoing auditor $\quad .822$

Auditor's disclose non-audit fees paid to them by the same client $\quad .766$

Auditor competence $(A C)$

The auditor has the ability to detect accounting/procurement

misstatements

This audit firm is willing to oblige proper accounting/procurement treatments

Audit firm staff are accounting/procurement professionals and as such are regulated

The audit staff have the necessary audit experience of NGO sector

Our auditors can complete assignments within the shortest time possible

Audit staff are well trained to handle accountancy/procurement work we give them

Auditor tenure (AT)

Longer auditor stay with the client helps them to do their work better

You appreciate your client's operations with time

Your long stay with client does not lead you to favour management

Even with a long tenure, auditor scepticism may not be hampered

Auditors will apply strong audit procedures irrespective of tenure length

Audit quality $(A Q)$

Our auditor will detect and report a material misstatement

Audits support to improve the quality of financial/procurement and program reporting

Use of big four by NGOs helps them to get more donor funding

Our financial/procurement and other internal processes operate

efficiently

The presence of audit systems is well embraced by NGOs

Number of audit Assignments (AN)

Having many assignments affects the work of your auditors

Having more clients usually overstretches your auditors to detect errors Your auditor is always busy to provide adequate time to the organisation

Initial Eigen values
Eigen values after rotation
Total percentage variance
Cumulative variance $(\%)$

Note: A principal component analysis with Varimax rotation was used, based on a sample size of 246, Bartlett's test of sphericity sig. $<0.001$ and Kaiser-Meyer-Olkin (KMO) sig. $=0.889$. 
To be able to conduct descriptive and relational analyses, the scale observed variables for each of the constructs were combined into a single variable using averages. This was done by computing a new variable for all the variable items represented by the variable factors that have been identified in the factor analysis.

The model specification

The new variables computed are presented in the models that follows hereunder that were used to examine the determining factors of audit quality

audqual $=\beta_{0}+\beta_{1}$ fsize $+\beta_{2}$ audfees $+\beta_{3}$ audind $+\beta_{4}$ audcomp $+\beta_{5}$ audtenu $+\beta_{6}$ audassign $+\beta_{7}$ audage $+\varepsilon \ldots \ldots \ldots$ (i) where,

$\beta_{0}=$ Constant

$\beta_{1-} \beta_{7}=$ Coefficient of parameter estimates

audqual $=$ Audit quality

$f_{\text {size }}=$ Firm size

audfees $=$ Auditor fees

audind $=$ Auditor independence

audcomp $=$ Auditor competence

audtenu $=$ Auditor tenure

audassign $=$ number of audit assignments

audage $=$ Auditor's age in years

$\varepsilon=$ an error term

However, considering the fact that perceptions about the work of internal and external auditors could be different among finance/procurement managers, it was necessary to identify if there are any differences between their responses. This means that model (i) can be respecified to include the dummy variable which takes on the value of zero ( 0 ) for external auditor responses and the value of one (1) for internal auditor responses. Where our results return a significant dummy variable, this would suggest significant differences in audit quality perceived between external and internal auditors in their practice.

Therefore;

audqual $=\alpha+\beta_{1}$ ssize $+\beta_{2}$ audfees $+\beta_{3}$ audind $+\beta_{4}$ audcomp $+\beta_{5}$ audtenu $+\beta_{6}$ audassign $+\beta_{7}$ audage $+\beta_{8} d u m m y$ $+\varepsilon \ldots$. (ii)

Table 3: Descriptive Statistics

\begin{tabular}{llllll}
\hline Variable & $\mathrm{N}$ & Mean & Std. Deviation & Items & Cronbach $\alpha$ \\
\hline audqual & 246 & 3.27 & 0.32 & 5 & .813 \\
size & 246 & 3.36 & 0.34 & 5 & .811 \\
audfees & 246 & 3.56 & 0.78 & 3 & .801 \\
audind & 246 & 3.33 & 0.36 & 8 & .899 \\
audcomp & 246 & 3.91 & 0.56 & 6 & .798 \\
audtenu & 246 & 3.38 & 0.31 & 6 & .776 \\
audassign & 246 & 3.07 & 0.65 & 3 & .788 \\
\hline
\end{tabular}

Source: Primary data

All variables used in this study are audit quality as dependent variable and five other explanatory variables: perceptions of firm size, auditor fees, auditor independence, the number of audit assignments of the auditor and auditor tenure. Each facet was examined using the mean, standard deviation, and Cronbach's alpha coefficients, see Table 3. Auditor competence generated the highest mean (3.91), followed by auditor fees (3.56), auditor tenure (3.38), auditor firm size (3.36), number of audit assignments handled by an auditor (3.07) and lastly auditor independence (3.33).

\section{Findings and discussions}

We present bivariate correlations and regression analyses about the relationships that exists between the determining factors of audit quality and themselves as well as audit quality which is true for correlations. Regression analyses reveal the extent to which the determining factors influence audit quality among NGOs in Uganda.

\subsection{Correlations}

Findings in Table 4 reveal that auditor independence has a significant positive correlation $\left(r=.375^{* *}, p \leq .01\right)$ with audit quality, as well as auditor fees $\left(\mathrm{r}=.308^{* *}, \mathrm{p} \leq .01\right)$ with audit quality. The same results are revealed between firm size $\left(r=.180^{* *}, p \leq .01\right)$ with audit quality, and auditor competence $\left(r=.210^{* *}, p \leq .01\right)$ with audit quality. This may be an indication that auditor independence, auditor fees, firm size and auditor competence could be determining factors of audit quality. 
Table 4: Correlation Matrix

\begin{tabular}{lllllllll}
\hline Variables & audind & audage & fsize & audqual & audcomp & audassign audtenu & audfees \\
\hline audind & 1 & $.482^{* *}$ & .056 & $.375^{* *}$ & .032 & $-.206^{* *}$ & -.109 & $.243^{* *}$ \\
audage & $.482^{* *}$ & 1 & .090 & -.103 & -.023 & $-.132^{* *}$ & .106 & $.137^{* *}$ \\
fsize & .056 & .090 & 1 & $.180^{* *}$ & $.375^{* *}$ & $.220^{* *}$ & $.192^{* *}$ & $.112^{*}$ \\
audqual & $.375^{* *}$ & -.103 & $.180^{* *}$ & 1 & $.210^{* *}$ & $-.200^{* *}$ & .131 & $.308^{* *}$ \\
audcomp & .032 & -.023 & $.375^{* *}$ & $.210^{* *}$ & 1 & $.298^{* *}$ & $.301^{* *}$ & .093 \\
audassign & $-.206^{* *}$ & $-.132^{* *}$ & $.220^{* *}$ & $-.200^{* *}$ & $.298^{* *}$ & 1 & $.255^{* *}$ & $-.225^{* *}$ \\
audtenu & -.109 & .106 & $.192^{* *}$ & .131 & $.301^{* *}$ & $.255^{* *}$ & 1 & $.212^{* *}$ \\
audfees & $.243^{* *}$ & $.137^{* *}$ & $.112^{*}$ & $.308^{* *}$ & .093 & $-.225^{* *}$ & $.212^{* *}$ & 1
\end{tabular}

**. Correlation is significant at the 0.01 level (2-tailed).

*. Correlation is significant at the 0.05 level (2-tailed).

On the other hand, auditor's age negatively but insignificantly $(r=-.103, p \leq .05)$ correlates with audit quality, however, the number of audit assignments negatively correlates significantly with audit quality $(r=-.200 * *, p$ $\leq .01)$. The indication is that of the two variables, many assignments may reduce the effectiveness of an auditor to conduct quality audits.

\subsection{Regression analysis}

Table 5 results are from model 1 specified "examining the relationship between all the independent variables (auditor independence, firm size, auditor fees, auditor tenure, number of audit assignments, auditor competence and auditor age) on audit quality. The model does not consider the effects of the dummy variable that reflect the effect of the nature of internal or external auditors. Overall, the model explains $24.6 \%$ of audit quality as a dependent variable given that adjusted R Square was .246. The model was well specified to reflect the overall effect of the explanatory variables on audit quality after introducing the dummy variable, since the $F$ statistic of 21.883 is realized and is significant at $p<.001$. Results indicate that auditor competence, auditor independence, firm size and auditor fees have positive significant relationship with audit quality, while the number of audit assignments has negative significant effects on audit quality. The rest of the independent variables such as auditor age and auditor tenure do not have significant effects on audit quality among NGOs in Uganda.

Auditor firm size $(\beta=0.111, \mathrm{t}=2.277, p=0.023)$ has been found to have a significant positive relationship with audit quality in line with hypothesis H1. This result is consistent with the assertions of Ndubuisi \& Ezechukwu (2017) and Mahdi \& Ali (2009) who find that the size of the firm matters a lot in ensuring audit quality. To these scholars, big firms can perform more accurate audit tests since they are normally well endowed with talented employees and superior technology which may support their cutting-edge audit performance compared to their small counterparts. This also implies that minimal error and misstatements arising from management self-interest behaviour could be found in financial and procurement statements audited by large firms.

Table 5: Model 1- Regression Results

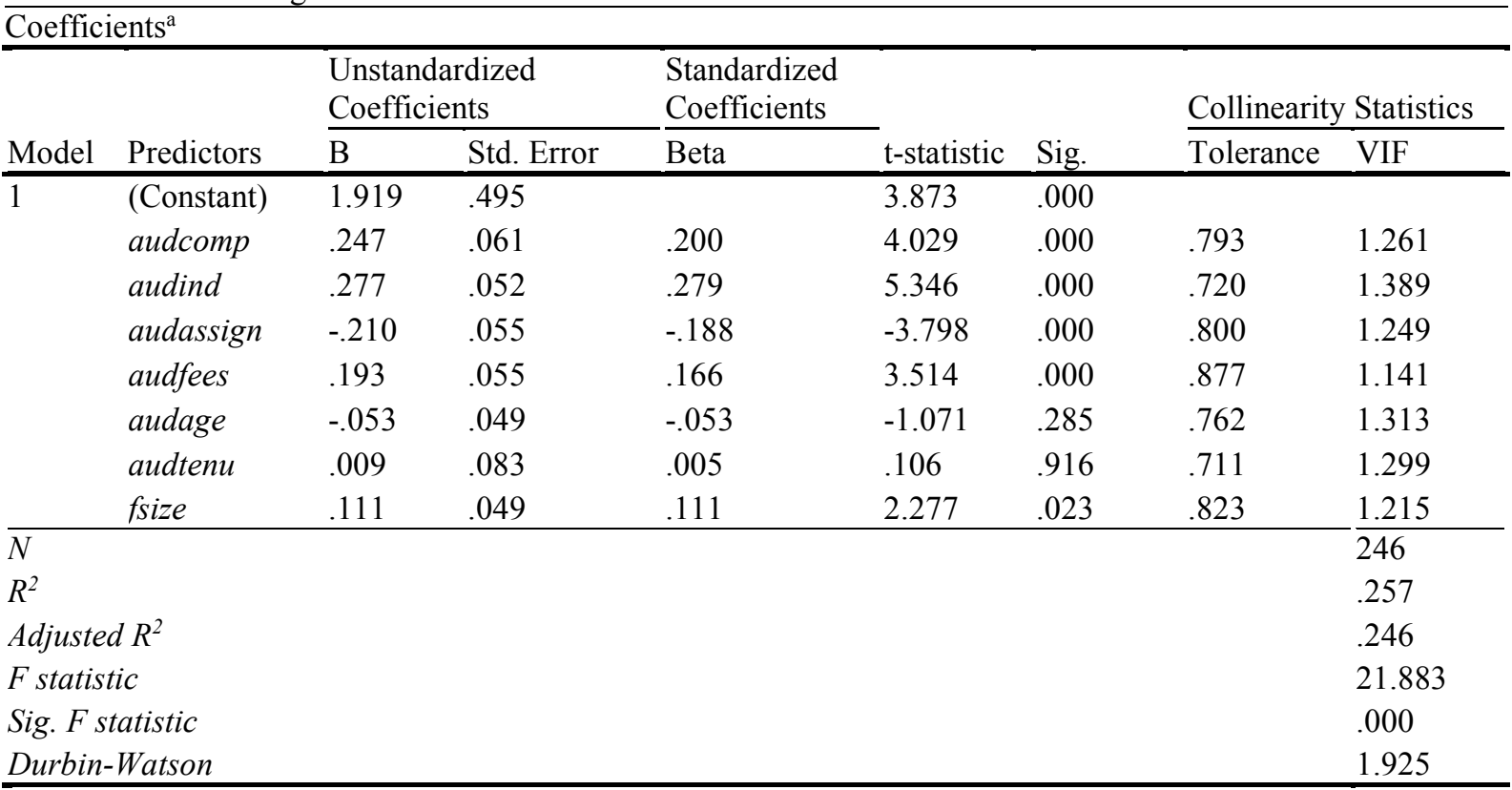

a. Dependent Variable: audqual 
Also, auditor fees have been found to have a positive relationship with audit quality that is statistically significant $(\beta=0.166, \mathrm{t}=3.514, p<0.001)$. This is also consistent with our hypothesis $\mathrm{H} 2$, which is in fact in line with Francis \& Simon (1987) who suggest that audit service quality can be differentiated by audit fees charged, meaning that the higher the auditor fees the better the quality. This does not however mean that lower auditor fees could signal lower audit quality. This is because Deis \& Giroux (1996) find that initial audits with new clients might actually be linked to lower audit fees but with higher audit quality since it's only used as a way to get new clients. This would therefore mean that managers of NGOs are likely to incur lower auditor fees initially but subsequently higher audit fees as long as they believe that the firm is going to deliver audit services of higher audit quality. Despite the mixed results by many scholars (see, Lim \& Tan, 2008; Chung \& Kallapur, 2003), the inconsistency might be as a result of excessive auditor fees charged (Choi et al. 2010) which might not be practiced among NGOs in Uganda.

Results also show that auditor independence $(\beta=0.279, \mathrm{t}=5.346, p<0.001)$ and audit quality are positively and statistically significant. This supports hypothesis H3, which consistent with results from various studies (See; Ramadhanis, 2012; Arisinta, 2013; Darayasa \& Wisadha, 2016; Chariri et al. 2017). This means that improving auditors' independence is key to enhancing audit quality. Such could be done through engagement controls instituted in audit processes and audit service, and through internal governance measures like codes of ethics and oversight of auditors. Once independence is secured as indicated by Kaawaase and Nkundabanyanga (2017), audit quality is the ultimate as the auditor will be in position to issue an objective audit report that can be used in decision making by the stakeholders.

Findings further reveal that auditor competence is statistically and significantly related to audit quality for NGOs in Uganda $(\beta=0.200, \mathrm{t}=4.029, p<0.001)$, which supports hypothesis H4. This finding is consistent with a number of scholars (DeAngelo, 1981; Puspitasari et al. 2019; Sari \& Susanto, 2018; Abbott et al. 2016) who believe that a competent auditor is high likely to discover and report errors and misstatements within the reporting system. By implication auditors should keep abreast with the current professional knowledge to allow them compete favourably within the audit profession and market. This can be done through continuing professional education in order for auditors to preserve and expand their capabilities (Al-Khaddash, et al. 2013). This can therefore, improve auditors' understanding of the client's business processes as well as the audit reports. On the contrary, auditor tenure $(\beta=0.005, \mathrm{t}=.106, p>0.05)$ has been found to be insignificantly related to audit quality among NGOs operating in Uganda which is inconsistent with hypothesis H6.

The number of audit assignments and audit quality have been found to be negatively and significantly related $(\beta=-0.188, \mathrm{t}=-3.798, p<0.001)$, consistent with hypothesis H7. This implies that any small increase in the number of audit assignments is likely to reduce the level of audit quality. This finding is consistent with Persson (2011) who report that increases in number of audit assignments might reduce the overall time the auditor would spend on each assignment. Hence audit quality since the quality control mechanisms might reduce. It could also be true as many assignments might overstretch the auditors (Jiraporn et al. 2009) hence retarding audit performance. This is however inconsistent with the argument that auditors might benefit out of holding many assignments since their competences complying with audit procedures and writing audit reports might improve (Vander Bauwhede \& Willekens, 2004). Lastly, findings reveal that auditor's age may not have any effect on audit quality as was hypothesised in $\mathrm{H} 8(\beta=-0.053, \mathrm{t}=-1.071, p>0.05)$.

Model 2examines the effects of all independent variables on audit quality together with a dummy variable relating to whether the audit assignment was done by an internal or external auditor.

audqual $=\alpha+\beta_{1}$ ssize $+\beta_{2}$ audfees $+\beta_{3}$ audind $+\beta_{4}$ audcomp $+\beta_{5}$ audtenu $+\beta_{6}$ audassign $+\beta_{7}$ audage $+\beta_{8} d u m m y$ $+\varepsilon \ldots$. (ii)

Table 6 (model 2 results) helps in confirming hypothesis H5. Findings reveal that there were no significant differences between the responses made for internal and external auditors' work $(\beta=0.002, \mathrm{t}=.031, p>0.05)$. This finding means that both internal and external auditors are likely to discover errors and misstatements and report them (DeAngelo, 1981). With the requisite professional competences, the audit quality of both internal and external auditors is expected to be high. This might demand that internal and external auditors keep up to the game with continuous professional trainings (Hardiningsih et al., 2019) so that they are able to institute reasonable audit procedures as they perform their work. This is likely to create harmony in the quality of audits between internal and external auditors that undertake work among NGOs in Uganda. The results following the effects of the other independent variables remained unchanged as in model 1 after the introduction of a dummy variable (see,Table 6). 
Table 6: Model 2- Regression Results Coefficients $^{\text {a }}$

\begin{tabular}{|c|c|c|c|c|c|c|}
\hline \multirow[b]{2}{*}{ Model } & \multirow[b]{2}{*}{ Predictors } & \multicolumn{2}{|c|}{ Unstandardized Coefficients } & \multirow{2}{*}{$\begin{array}{l}\text { Standardized } \\
\text { Coefficients } \\
\text { Beta }\end{array}$} & \multirow[b]{2}{*}{ t-statistic } & \multirow[b]{2}{*}{ Sig. } \\
\hline & & $\mathrm{B}$ & Std. Error & & & \\
\hline \multirow[t]{9}{*}{1} & (Constant) & 2.187 & .535 & & 4.088 & .000 \\
\hline & audcomp & .270 & .064 & .219 & 4.241 & .000 \\
\hline & audind & .279 & .052 & .281 & 5.386 & .000 \\
\hline & audassign & -.191 & .057 & -.170 & -3.328 & .001 \\
\hline & audfees & .186 & .055 & .160 & 3.374 & .001 \\
\hline & fsize & .128 & .050 & .129 & 2.548 & .011 \\
\hline & audage & -.098 & .074 & -.071 & -1.323 & .187 \\
\hline & audtenu & .010 & .081 & .006 & .123 & .899 \\
\hline & dummy & .003 & .087 & .002 & .031 & .976 \\
\hline \multicolumn{2}{|l|}{$N$} & & & & & 246 \\
\hline \multicolumn{2}{|c|}{$R^{2}$} & & & & & .261 \\
\hline \multicolumn{2}{|c|}{ Adjusted $R^{2}$} & & & & & .248 \\
\hline \multicolumn{2}{|c|}{ F statistic } & & & & & 19.044 \\
\hline \multicolumn{2}{|c|}{ Sig. F-statistic } & & & & & .000 \\
\hline \multicolumn{2}{|c|}{ Durbin-Watson } & & & & & 1.936 \\
\hline
\end{tabular}

a. Dependent Variable: audqual

\section{Conclusions}

We have examined the determining factors of audit quality among NGOs in Uganda, and established that auditor competence, auditor independence, firm size and auditor fees are likely to increase audit quality, whereas the more number of audit assignments handled reduce audit quality since auditors may not find appropriate time to properly execute audit assignments. Also, the study does not find significant effects between auditor tenure and auditor age on audit quality in the view of NGO finance/procurement staff. As well the study does not find any significant differences in the responses of the finance/procurement staff about internal and external auditors' work. These findings present implications for auditors and audit firms in optimising their quality as perceived by the finance staff in the NGO sector.

It is worth noting that since this study used cross-sectional research design, the possibility of monitoring the changes that would occur to the perceptions of the finance/procurement staff on the quality of audits as auditors perform their audit assignments over time might be limited. Further research may analyse the relationship between the audit quality determinants and audit quality in the public sector enterprises and NGOs in Uganda and those located in countries where the legal requirements are different. This research especially perceptions in the area of auditor tenure and auditor age might further add to audit quality theory that this study contributes to.

\section{References}

Abbott, L. J., Daugherty, B., Parker, S., \& Peters, G. F. (2016). Internal Audit Quality and Financial Reporting Quality: The Joint Importance of Independence and Competence. Journal of Accounting Research, 54(1), 340. https://doi.org/10.1111/1475-679X.12099

Abbott, L. J., Parker, S., \& Peters, G. F. (2004). Audit committee characteristics and restatements. Auditing, 23(1), 69-87. https://doi.org/10.2308/aud.2004.23.1.69

Abbott, L. J., Parker, S., Peters, G. F., \& Raghunandan, K. (2003). The association between audit committee characteristics and audit fees. Auditing, 22(2), 17-32. https://doi.org/10.2308/aud.2003.22.2.17

Al-Khaddash, H., Al Nawas, R., \& Ramadan, A. (2013). Factors affecting the quality of Auditing: The Case of Jordanian Commercial Banks. International Journal of Business and Social Sciences, 4(3), 206-222.

All European Academies (2013). Ethics Education in Science. The Permanent Working Group on Science and Ethics. www.allea.org/wp-content/uploads/2015/07/Statement_Ethics_Edu_web_final_2013_10_10.pdf

Alqam, M. \& Alrajabi, T. (1997). The factors which lead to change the external auditor in the Jordanian public companies: Field study. Dirasat Journal, 24(1), 185-204.

Ashkanasy, N.M., \& Windsor, A. C. (1997). Personal and organisational factors affecting auditor independence: Empirical evidence and directions for future research. Accounting, Organisations and Society, 3, 35-48.

Beatty, R. P. (1989). Auditor reputation and the pricing of initial public offerings. The Accounting Review, 64(4), 693-709.

Brown, J., Falaschetti, D. \& Orlando, M. (2006). Auditor independence and earnings quality. Working paper, Montana State University. 
Chaney, P., Jeter, D. \& Shivakumar, L. (2002). Audit pricing in private firms. Working paper, Owen Graduate School of Management, Vanderbilt University.

Choi, J. H., Kim, J. B., \& Zang, Y. (2010). Do abnormally high audit fees impair audit quality? Auditing: A Journal of Practice \& Theory, 29(2), 115-140. https://doi.org/10.2308/aud.2010.29.2.115

Christiawan, Y. J. (2002). Kompetensi dan independensi akuntan publik: refleksi hasil penelitian empiris. Jurnal Akuntansi \& Keuangan, 4(2), 79-92.

Chung, H., \& Kallapur, S. (2003). Client importance, non-audit services, and abnormal accruals. The Accounting Review, 78(4), 931-955.

Colbert, G., \& Murray, D. (1998). The association between audit quality and auditor size: An analysis of small CPA firms. Journal of Accounting, Auditing and Finance, 13, 135-150.

Conroy, S. J., Emerson, T. L. N., \& Pons, F. (2010). Ethical attitudes of accounting practitioners: Are rank and ethical attitudes related? Journal of Business Ethics, 91(2), 183-194. https://doi.org/10.1007/s10551-0090076-2

Core, E. J., Holthausen, W. R. \& Larcker, F. D. (1999). Corporate Governance, Chief Executive Officer Compensation, and Firm Performance. Journal of Financial Economics, 51, 371-406.

Craswell, A. T., Francis, R. J. \& Taylor, L. S. (1995). Auditor brand name reputations and industry specialization. Journal of Accounting and Economics, 20, 297-322.

Damba R. (2018). Of What value are NGOs to Uganda?” Available at https://www.ngoforum.or.ug/2018/05/30/ofwhat-value-are-ngos-to-uganda

DeAngelo, L. E. (1981). Auditor size and audit quality. Journal of Accounting and Economics, 3(3), $183-199$. https://doi.org/10.1016/0165-4101(81)90002-1

Deis, D. R., \& Giroux, G. (1996). The effect of auditor changes on audit fees, audit hours, and audit quality. Journal of Accounting and Public Policy, 15(1), 55-76. https://doi.org/10.1016/0278-4254(95)00041-0

Deis, D. R., \& Giroux, G. A. (1992). American Accounting Association Determinants of Audit Quality in the Public Sector. The Accounting Review, 6784(3), 462-479.

Dopuch, N., \& Simunic, D. (1982). Competition in auditing: An assessment. Paper presented at a symposium on Auditing Research IV, University of Illinois at Urbana-Champaign.

Dunn, K. A., \& Mayhew, B. W. (2004). Audit firm industry specialization and client disclosure quality. Review of Accounting Studies, 9(1), 35-58. https://doi.org/10.1023/B:RAST.0000013628.49401.69

European Research Administrators (2017). Guidelines for ensuring compliance with ethical principles in Horizon 2020 - from proposal to Grant Agreement.

Favere-Marchesi, M. (2000). Audit quality in ASEAN. International Journal of Accounting, 35(1), 121-149. https://doi.org/10.2469/dig.v30.n4.753

Ferdinand, Syaifuddin, D, T., Dali, N., \& Masud, A. (2019). Effects of Competence and Independence as Well as Professional Attitude on Audit Quality and Individual Characteristics as Moderating-A Study on Internal Auditors in Southeast Sulawesi Province. International Journal of Civil Engineering and Technology (IJCIET), 10(7), 184-200.

Ferris, S. P., Jagannathan, M. \& Pritchard, A. C. (2003). Too Busy to Mind the Business? Monitoring by Directors with Multiple Board Appointments. The Journal of Finance, LVII(3), 1087-1111.

Fich, M. E. \& Shivdasani, A. (2006). Are Busy Boards Effective Monitors? The Journal of Finance, LXI(2), 689724.

Francis, J. R. \& Simon, T. D. (1987). A test of audit pricing in the small-client segment of the USA: Audit Market. The Accounting Review, 62(1), 142-157.

González-Díaz, B., García-Fernández, R., \& López-Díaz, A. (2015). Auditor tenure and audit quality in Spanish state-owned foundations. Revista de Contabilidad-Spanish Accounting Review, 18(2), 115-126. https://doi.org/10.1016/j.rcsar.2014.04.001

Hardiningsih, P., Januarti, I., Oktaviani, R. M., Srimindarti, C., \& Udin, U. (2019). Determinants of audit quality: an empirical insight from Indonesia. International Journal of Scientific \& Technology Research, 8(07), 570578.

Hawkins, D.G, Lake, A.D., Nielson, L.D., \& Tierney, J.M. (2006). Delegation under anarchy: States, International Organizations, and Principal-Agent Theory." In Delegation and Agency in International Organizations, ed. Darren G Hawkins, David A Lake, Daniel L Nielson, and Michael J Tierney. Cambridge: Cambridge University Press.

Horvat, T., \& Bobek, V. (2019). Planning the Audit of Financial Resources in a Non-Profit Organization. Intech Open, 1-20. http://dx.doi.org/10.5772/intechopen. 88450

Jiraporn, P., Davidson III, W. N., DaDalt, P. \& Ning, Y. (2009). Too Busy to Show Up? An Analysis of Directors' Absences. The Quarterly Review of Economics and Finance, 49, 1159-1171.

Joe, R. J. \& Vandervelde, D. S. (2007). Do Auditor-provided Non-Audit Services Improve Audit Effectiveness? Contemporary Accounting Research, 24(2), 467-487. 
Joint Inspection Unit (2017). Review of Donor Reporting Requirements across the United Nations System. JIU/REP/2017/7 Original: English. Geneva.

Kaawaase, K.T., \& Nkundabanyanga, K.S. (2017). Perceived auditor independence factors in Uganda. Makerere Business Journal, 13(2), 128-153.

Kasigwa, G., Munene, C. J., Ntayi, J., \& Nkote, I. (2013). Reduced audit quality behavior among auditors in Uganda. African Journal of Accounting, Economics, Finance and Banking Research, 9(9), 25-37.

Kinney, W. R., \& Libby, R. (2002). Discussion of the relation between auditors' fees for non-audit services and earnings management. The Accounting Review, 77(Supplement), 107-114.

Knechel, W. R., \& Vanstraelen, A. (2007). The relationship between auditor tenure and audit quality implied by going concern opinions. Auditing: A Journal of Practice \& Theory, 26(1), 113-131. https://doi.org/10.2308/aud.2007.26.1.113

Krishnan, J. \& Schauer, P. (2000). The differentiation of quality among auditors: Evidence from the not-for-profit sector auditing. A Journal of Practice and Theory, 19(2), 9-25.

Lennox, C. S. (2010). Non-audit fees, disclosure and audit quality. The European Accounting Review, 8(2), 239252. https://doi.org/10.1080/096381899336014

Lim, C. Y., Tan, H., \& Cheng, Q. (2010). Does Auditor Tenure Improve Audit Quality? Moderating Effects of Industry Specialization and Fee Dependence. Contemporary Accounting Research, 27(3), 923-957.

Lim, C., \& Tan, H. (2008). Non-audit service fees and audit quality: The impact of auditor specialization. Journal of Accounting Research, 46(1), 199-246. https://doi.org/10.1111/j.1475-679X.2007.00266.x

Loderer, C. \& Peyer, U. (2002). Board Overlap, Seat Accumulation and Share Prices. European Financial Management, 8(2), 165-192.

Magill, H. T. \& Previts, J. G. (1991). CPA professional responsibilities: An Introduction. Cincinnati, OH, SouthWestern Publishing Co, Inc.

Manley, M. (2018). Manage International NGO Risk Effectively with an External Field Office Audit. GRF CPAs and Advisors. Accessed on 29 December 2020 from: https://www.grfcpa.com/2018/08/manage-internationalngo-risk-effectively-with-an-external-field-office-audit/

Mansouri, A., Pirayesh, R., \& Salehi, M. (2009). Audit Competence and Audit Quality: Case in Emerging Economy. International Journal of Business and Management, 4(2), 17-25. https://doi.org/10.5539/ijbm.v4n2p17

Mubiru, A. (2020), Improve audit quality, accountants told. New Vision of $24^{\text {th }}$ January 2020 . Accessed on $29^{\text {th }}$ December 2020 from: https://www.newvision.co.ug/news/1513923/improve-audit-quality-accountants-told

Ndubuisi, A. N., \& Ezechukwu, B. O. (2017). Determinants of audit quality: Evidence from deposit money banks listed on Nigeria Stock Exchange. International Journal of Academic Research in Accounting, Finance and Management Sciences, 7(2), 117-130. https://doi.org/10.6007/ijarafms/v7-i2/2877

Omonuk, J. B., \& Oni, A. A. (2015). Computer assisted audit techniques and audit quality in developing countries: Evidence from Nigeria. Journal of Internet Banking and Commerce, 20(3), 1-17. https://doi.org/10.4172/1204-5357.1000127

Pany, K. \& Reckers, J. M. P. (1988). Auditor performance of MAS: A study of its effects on decisions and perceptions. Accounting Horizons, 2(2), 31-38.

Persson, U. (2011). Factors Affecting Audit Quality: Number of Assignments and Age of the Auditor. Master Thesis, Umea School of Business.

Ponemon L. A. \& Gabhart, L. R. D. (1990). Auditor independence judgements: A cognitive-developmental model and experimental evidence. Contemporary Accounting Research, 7(1), 227-251.

Puspitasari1, A., Baridwan, Z., \& Rahman, F.A. (2019). The effect of audit competence, independence, and professional skeptism on audit quality with auditor's ethics as moderation variables. International Journal of Business, Economics and Law, 18(5), 135-144.

Retzl, K. J. (2017). Audits and Accountability in Non-Governmental Organizations.

Rezaei, F., \& Shabani, S. (2014). The effect of audit firm size and age on the quality of audit work. European Online Journal of Natural and Social Sciences, 3(1), 56-64.

Rhodes, S. R. (1983). Age-related differences in work attitudes and behavior: A review and conceptual analysis. Psychological Bulletin, 93(2), 328-367. https://doi.org/10.1037/0033-2909.93.2.328

Sari, N. Z. M., \& Susanto, A. (2018). The effect of auditor competency and work experience on information systems Audit quality and supply chain (case study: Indonesian Bank). International Journal of Supply Chain Management, 7(5), 747-750.

Schelluch, P \& Thorpe, S. (1995). Perceptions of auditor independence: Perspective of Contemporary auditing. Audit Centre of Excellence, Australian Society of CPAs.

Schuetze, W. (1994). A mountain or a molehill. Accounting Horizons, 8(1), 69-75.

Schwartz, K. B. \& Menon, K. (1985). Auditor switches by failing firms. The Accounting Review, 60(April), 248261. 
Shockley, R (1981). Perceptions of auditor independence. The Accounting Review, 56(4), 785-800.

Suseno, N. S., \& Nofianti, L. (2018). Empirical Evidence of Audit Firm Size Toward Audit Quality and Reputation of Public Accounting Firm. Advanced Science Letters, 24(5), 3327-3331. https://doi.org/10.1166/asl.2018.11367

UNHCR bipartite model (2014). Standard Format Bipartite Project Partnership Agreement (UNHCR with nongovernmental and other not-for-profit partners).

USAID (2010). The Essential NGO Guide to Managing Your USAID Award. United States Agency for International Development. NW Washington, DC 20009-5721, p 64-65.

Bauwhede, H. V., \& Willekens, M. (2004). Evidence on (the Lack of) Audit-quality Differentiation in the Private Client Segment on the Belgian Audit Market. European Accounting Review, 13(3), 501-522.

Watts, R. L. \& Zimmerman, J. L. (1986). Positive Accounting Theory. Prentice Hall. New Jersey.

Wright, A. \& Wright, S. (1997). An examination of factors affecting the decision to waive audit adjustments. Journal of Accounting, Auditing and Finance, 12, 15-36.

Yamani, A. (1991). The factors that affect external auditor independency from point of views the analysts and borrowers in the Saudi Arabia. General Management Journal, Al Riyadh, 71, 183-229.

Zu'amah, S. (2009). Independensi dan kompetensi auditor pada opini audit studi bpkp jateng. Jurnal Dinamika Akuntansi 1(2), 145-154. 